\title{
System Productivity and Energetics of High-Value Crops Embedded Diversified Cropping Systems
}

\author{
B. Bhargavi ${ }^{1,3^{*}}$ and U.K. Behera ${ }^{2,3}$ \\ ${ }^{1}$ Division of Crop production, ICAR Central Institute for Cotton Research, Nagpur, \\ Maharashtra-441108, India \\ ${ }^{2}$ Central Agricultural University, Umiam, Meghalaya -793103, India \\ ${ }^{3}$ ICAR-Indian Agricultural Research Institute, New Delhi 110012, India \\ *Corresponding author
}

Keywords

High-value crops,

Cropping systems,

System

productivity,

Profitability,

Energetics

Article Info

Accepted:

12 December 2018

Available Online:

10 January 2019

\section{A B S T R A C T}

A field experiment was conducted during 2 rainy (kharif), winter (rabi) and summer seasons (2015-17) on a sandy clay loam soil at New Delhi to evaluate 5 cropping systems viz., maize-pea-okra, maize-mustard-green gram, cotton-wheat, bottle gourd-onion and okra-wheat, for productivity, profitability and energetics. The experiment was laid-out in a randomized block design replicated 4 times. Bottle gourd-onion cropping system recorded the highest wheat-grain-equivalent yield (WGEY) of $19.9 \mathrm{t} / \mathrm{ha}$, followed by maize-peaokra (14.06 t/ha). The lowest WGEY was recorded with maize-mustard-green gram $(9.12$ t/ha). The gross returns $\left(\square 313.56 \times 10^{3} /\right.$ ha), net returns $\left(\square 123.5 \times 10^{3} /\right.$ ha), benefit: cost ratio (3.23), were also higher with bottle gourd-onion cropping system, while maizemustard-green gram registered the lowest gross returns, net returns and B: $\mathrm{C}$ ratio. The lesser input energy $\left(25.68 \times 10^{3} \mathrm{MJ} / \mathrm{ha}\right)$ and higher energy productivity $(775.2 \mathrm{~g} / \mathrm{MJ})$ was recorded with bottle gourd - onion cropping system. All the five cropping systems can suitably substitute the existing rice - wheat cropping system under marginal farmer's situations, not only by providing higher productivity and returns, but also provide a regular income throughout the year.

\section{Introduction}

In the Green Revolution areas of the IndoGangetic Plains (IGP), continued adoption of the rice-wheat system for over 4-decades has posed a serious threat to agricultural sustainability in that region (Bhatt et al., 2016). These problems include deterioration of land, build-up of obnoxious weeds, declining factor of productivity, plateauing of yield, receding water tables, loss of biodiversity and development of multiple nutrient deficiencies (Jain 2008, Bhullar and Chauhan 2015). Concerns about stagnating productivity, increasing production costs, declining resource quality, declining water tables and increasing environmental problems are the major forcing factors to look for alternative technologies in the IGP region of India. The traditional monoculture and 
disciplinary approach is unable to meet the growing and changing food demand and improve the livelihood of these smallholders on a sustainable basis (Mahapatra and Behera 2011). There is now a growing demand for agricultural diversification and reorientation of strategies with emphasis on resource conservation technologies for improving productivity on a sustainable basis. Crop diversification is very often advocated for alleviating the problems encountered in the post Green Revolution era (Behera et al., 2007).

Among rice and wheat cropping systems, irrigated rice, is a heavy water consumer as it took around 5000 litres of water to produce 1 $\mathrm{kg}$ of rice. Rice-wheat cropping system consumes about $11,650 \mathrm{~m}^{3} /$ ha water out of which $7650 \mathrm{~m}^{3}$ is by rice (Bhatt et al., 2016). Thus, the water table in IGP is declining down at alarming rates (Soni 2012). As a result submersible pumps replacing the centrifugal pumps which lift up water from the deeper depths but they required more energy for this purpose (Hira 2009). In the era of shrinking resource base of land, water and energy, resource use efficiency is an important aspect for considering the suitability of a cropping system. Hence, selection of component crops needs to be suitably planned to harvest the synergism among them towards efficient utilization of resource base and to increase overall productivity (Singh et al., 2017). With increasing purchasing power of people in the country, the demand for vegetable crops has increased enormously leading to sharp increase in their prices and it has been the dominant factor for high inflationary pressure in Indian economy during recent years. Inclusion of crops like oilseeds, pulses, vegetables and fodder crops will improve the economic condition of small and marginal farmers owing to higher price and/or higher volume of their main and by-products (Dasset al., 2009, Sharma et al., 2007). Hence, efforts are needed to promote diversification of ricebased cropping sequence in the country with high-value crops for sustaining the productivity and meet out demand for vegetables, pulses and oilseeds. Therefore, the present investigation was carried out to find out most productive, resource-use efficient and remunerative cropping system for IndoGangetic Plains region.

\section{Materials and Methods}

A field experiment was conducted from the rainy season (kharif) 2015 to summer 2017 at ICAR-Indian Agricultural Research Institute, New Delhi $\left(28^{\circ} 38^{\prime} \mathrm{N}\right.$ and $77^{\circ} 38^{\prime} \mathrm{E}, 228.6 \mathrm{~m}$ above mean sea-level). The meteorological data of maximum temperature, minimum temperature, evaporation and rainfall for the period of experimentation (i.e. June 2015 to May 2017) were recorded at the meteorological observatory of ICAR-IARI, New Delhi. The climate of above unit is semiarid with dry, hot summers and cold winters with an average annual rainfall of $1088 \mathrm{~mm}$, $83 \%$ of which is received through south-west monsoon during July-September. Soil of the experimental field was sandy clay loam in texture, slightly alkaline in reaction ( $\mathrm{pH}$ 6.9), low in organic carbon $(0.38 \%)$, available nitrogen $(251.8 \mathrm{~kg} / \mathrm{ha})$, available phosphorus $(11.2 \mathrm{~kg} / \mathrm{ha})$ and medium in potassium (254 $\mathrm{kg} / \mathrm{ha})$.

The experiment was carried out in randomized block design replicated four times. The treatments include 5-cropping systems, viz. maize (Zea mays) - pea (Pisum sativum) okra (Abelmoschus esculentus), maize (Zea mays) - mustard (Brassica juncea) - green gram (Vigna radiata), cotton (Gossypium hirsutum) - wheat (Triticum aestivum), bottle gourd (Lagenaria siceraria) - onion (Allium cepa) and okra (Abelmoschus esculentus) wheat (Triticum aestivum). The net plot size of each treatment was $150 \mathrm{~m}^{2}$. 
The details of varieties used, seed rate, fertilizer doses and spacing are given in Table 1. Nitrogen, phosphorus and potassium were applied through urea, di-ammonium phosphate and muriate of potash, respectively. In maize, half dose of nitrogen and full doses of phosphorus and potassium were applied at the time of sowing, while remaining $\mathrm{N}$ was applied 1 month after sowing. In cotton, half of $\mathrm{N}$ and full dose of $\mathrm{P}$ and $\mathrm{K}$ were given at the time of sowing and remaining was given before flowering. Full doses of N, P and K were applied at sowing time in bottle gourd. One-third of N, P and $\mathrm{K}$ at sowing and remaining two splits at 4 weeks and 8 weeks after sowing in okra. At physiological stage of maturity, all the crops were harvested manually. After drying in the sun, the total biomass was weighed. Economic yield was recorded for all the crops. After harvesting of kharifcrops, rabicrops were sown in the same plots without disturbing the layout as per recommended package of practices mentioned in Table 1. In wheat half dose of nitrogen and full doses of $\mathrm{P}$ and $\mathrm{K}$ were applied at the time of sowing, while remaining nitrogen was topdressed at the first irrigation. Half of $\mathrm{N}$ and full dose of $\mathrm{P}$ and $\mathrm{K}$ at the time of sowing of mustard and remaining half dose of nitrogen was applied after one month of sowing. In onion one-third dose of $\mathrm{N}$ and full dose of $\mathrm{P}$ and $\mathrm{K}$ were applied with last field operation. Remaining two-third $\mathrm{N}$ was given in two equal splits after 30 and 60 days after transplanting. After harvesting of rabi crops, summer crops, viz. green gram and okra, were raised as per treatments without disturbing the original layout following standard package of practices (Table 1). Green gram was harvested at physiological stage of maturity while 5-6 pickings of okra were taken to harvest it in green and immature stage.

Economic yields of the component crops were converted to wheat-grain-equivalent yield (WGEY), taking into account the prevailing minimum support price/market prices of the crops (Uddin et al., 2009). System productivity was calculated by adding the WGEY of the component crops. For estimation of energy inputs and outputs for each item of inputs and agronomic practices, equivalents were utilized as suggested by Mittal and Dhawan (1988), Baishaya and Sharma (1990), Panesar and Bhatnagar (1994) and Singh et al., (1997). Energy efficiency, energy productivity and specific energy were calculated using the following formula as suggested by Singh et al., (1997) and Burnett (1982).

\section{Results and Discussion}

\section{Performance of crops and cropping systems}

Economic yield and stover yield of individual crop have been given in tables 2 and 3 .

\section{CS-1: Maize - pea - okra}

The grain yield of maize was 4.14 and 4.78 t/ha during 2015 and 2016, respectively. Similarly, stover yield was 7.04 and 7.36 t/ha during 2015 and 2016, respectively. The green pod yield of pea during 2015-16 and 2016-17 was found to be 1.37 and $1.56 \mathrm{t} / \mathrm{ha}$, respectively. The stover yield and biomass obtained from pea was 2.94, 4.31 t/ha and $3.21,4.77 \mathrm{t} / \mathrm{ha}$, respectively during the study period. The fruit yield of okra recorded during 2016 and 2017 was 3.39 and 3.01 t/ha, whereas the stover yield was 3.73 and 3.22 t/ha, respectively.

\section{CS-2: Maize - mustard - green gram}

The grain yield of maize was 4.27 and 4.47 t/ha during 2015 and 2016, respectively. Similarly stover yield was 7.16 and 7.22 t/ha during 2015 and 2016, respectively. The seed yield of mustard during 2015-16 and 2016-17 was found to be 1.61 and $1.42 \mathrm{t} / \mathrm{ha}$, 
respectively. The pod yield of green gram recorded during 2016 and 2017, was 0.48 and $0.61 \mathrm{t} / \mathrm{ha}$, whereas the stover yield was 0.68 and $0.73 \mathrm{t} / \mathrm{ha}$, respectively.

\section{CS-3: Cotton - wheat}

The yield of seed cotton was 1.95 and 2.14 t/ha during 2015 and 2016, respectively. Similarly stover yield was 4.85 and 5.43 t/ha during 2015 and 2016, respectively. The grain yield of wheat during 2015-16 and 2016-17 was found to be 5.12 and 5.25 t/ha, respectively. The straw yield obtained from wheat was $6.86,6.97 \mathrm{t} / \mathrm{ha}$, respectively during the study period.

\section{CS-4: Bottle gourd - onion}

Bottle gourd fruit yield during 2015 and 2016 was 8.12 and $8.26 \mathrm{t} / \mathrm{ha}$, respectively. Similarly stover yield was 3.28 and 3.54 t/ha during 2015 and 2016, respectively, whereas the bulb yield of onion during 2016 and 2017 was found to be 9.01 and $10.65 \mathrm{t} / \mathrm{ha}$, respectively. The stover yield obtained from onion was $1.42,1.27 \mathrm{t} / \mathrm{ha}$, respectively during the study period.

\section{CS-5: Okra - wheat}

The fruit yield of okra recorded during 2015 and 2016 was 5.67 and $6.42 \mathrm{t} / \mathrm{ha}$, whereas the stover yield was 3.41 and 3.28 t/ha, respectively. The grain yield of wheat during 2015-16 and 2016-17 was found to be 5.18 and $5.31 \mathrm{t} / \mathrm{ha}$ respectively. The straw yield obtained from wheat was 6.91, $7.08 \mathrm{t} / \mathrm{ha}$, respectively during the study period.

\section{System productivity}

The total productivity of various cropping systems was worked out after converting the economic yield of all the crops grown in sequence into wheat-grain-equivalent yield
(WGEY) (Table 3). Among the various cropping systems tried, system productivity was significantly higher in bottle gourd onion cropping system being 118.1, 89, 50.4 and $41.55 \%$ greater than maize - mustard green gram, cotton - wheat, okra-wheat and maize - pea - okra cropping systems, respectively. Higher tonnage and better price of both bottle gourd and onion played a vital role in improving the wheat-grain-equivalent yield. The next cropping system in the order was maize - pea - okra with WGEY of about 14.28 and 13.84 t/ha during 2015-16 and 2016-17, respectively. It can be attributed mainly to okra which fetched higher prices in the market besides having higher productivity. However, WGEY of maize - pea - okra was statistically at par with okra - wheat cropping system.

The system productivity was higher in cropping systems through the inclusion of high value crops i.e. vegetables. Mishra et al., (2007) also observed higher productivity with the inclusion of vegetables in rice - based cropping systems. These results are in line with the findings of Singh et al., (2007) who reported rice - pea - okra followed by rice pea - onion as the most productive cropping sequence for eastern Uttar Pradesh, India. The lowest WGEY was noticed in maize - mustard - green gram during both the years of experimentation, due to poor yields of mustard and green gram. These results corroborate with Prasad et al., (2013), who reported that wheat substituted by mustard or wheat + mustard $(5: 1)$ resulted in very poor performance of the system. It was apparent that poor yield of the mustard was responsible for lower REGY than rice- wheat sequence. It clearly shows the importance of summer crops to raise the system productivity and sustainability under irrigated conditions. The total productivity of the cropping systems was higher during second year of the study (201617 ) in comparison to the first year of the study 
(2015-16). This is attributed to higher temperatures during summer months in first year and residual effect of application of biogas slurry and farm yard manure produced within the farming system during first year, provided nutrients gradually to the crop, which is very much essential for nutrient exhaustive vegetable crops and cereals. The similar findings were reported by Khan et al., (2016) that $50 \%$ biogas slurry along with $50 \%$ chemical fertilizer gave highest crop growth and corn yield in baby corn.

\section{Economics}

Cost structure of different cropping systems was given in table 4 . The cost of cultivation per hectare was higher in maize - pea - okra cropping system (Table 4). To realize higher returns from the vegetable crops, farmers have to spend more on seed, fertilizer, labour, irrigation and adopt newer technologies. Besides, okra and onion crops required more man days for weeding and harvesting. So with inclusion of vegetables cultivation cost increased as compared to other cropping systems. Shah et al., (2015) and Prasad et al., (2013) also concluded that the inclusion of vegetables in the cropping system increased the total variable cost due to higher fertilization and human labour requirements. Jain et al., (2015) also reported that inclusion of vegetable (okra) increased the cost of cultivation. On the other hand, the lowest cost was expended in maize - mustard - green gram cropping system owing to less number of man-days and irrigations. Reddy (2014) also reported that the total cost per hectare was higher in high value crops (vegetables, fruits and flowers) followed by cotton, oilseeds, rice-wheat, pulse-cereal based, pulse based and the least in coarse cereal based cropping systems. Significantly higher net returns were realized from bottle gourd - onion cropping system ( $\square 216.34 \times 10^{3} / \mathrm{ha}$ ). Bottle gourd onion cropping system fetched an additional income of $92.84 \times 10^{3}, 142.95 \times 10^{3}, 136.89 \times$
$10^{3}$ and $94.54 \times 10^{3} \square /$ ha over maize - pea okra, maize - mustard - green gram, cotton wheat and okra - wheat cropping systems respectively. This was due to inclusion of vegetable crops (bottle gourd and onion) in the system, besides improving the system productivity due to their higher tonnage, fetched good market price thereby, increasing net returns. Besides, rising of vegetable crop (onion) during summer season is economically remunerative as supply of vegetables from rainfed area is drastically reduced and vegetable prices are much higher. Therefore surplus onion produced can be transported in areas of high demand even after 2-3 months after harvesting, as they have good shelf life. The next cropping system in the order was maize - pea - okra cropping system with $\square$ $123.50 \times 10^{3} /$ ha. Kumar et al., (2008) reported that inclusion of vegetable crops in rice based crop sequences improved the net returns. These results corroborate the findings of Jat et al., (2012). The lowest net returns of $\square 73.39 \times 10^{3}$ /ha was noticed with maize mustard - green gram system. This was due to lower yields from mustard and green gram. However, significantly higher benefit: cost ratio was recorded under bottle gourd - onion cropping system probably owing to higher returns in comparison to cost of cultivation.

\section{Energetics}

\section{Input energy}

Maize - pea - okra cropping system required higher input energy (33.07x $\left.10^{3} \mathrm{MJ} / \mathrm{ha}\right)$, this could be ascribed to higher requirement of primary inputs viz., seeds, fertilizer, labour etc. In vegetable crops (okra) there was an involvement of more number of labours in picking of fruits/pods followed by cotton wheat system $\left(31.96 \times 10^{3} \mathrm{MJ} / \mathrm{ha}\right)$. The lower input energy was used in bottle gourd - onion cropping system $\left(25.68 \times 10^{3} \mathrm{MJ} / \mathrm{ha}\right)$. This was because of less inputs like seed, irrigations and labour comparatively (Table 5). 
Table.1 Production technology adopted for raising crops during 2015-16 and 2016-17

\begin{tabular}{|c|c|c|c|c|c|c|c|c|c|c|c|c|}
\hline \multirow[t]{2}{*}{ Cropping system } & \multicolumn{3}{|c|}{ Variety } & \multicolumn{3}{|c|}{ Seed rate (kg/ha) } & \multicolumn{3}{|c|}{ Spacing $(\mathbf{c m} \times \mathbf{c m})$} & \multicolumn{3}{|c|}{$\begin{array}{l}\text { Fertilizer (kg/ha) } \\
\left(\mathrm{N}_{2} \mathrm{P}_{2} \mathrm{O}_{5}: \mathrm{K}_{2} \mathrm{O}\right)\end{array}$} \\
\hline & Kharif & Rabi & Summer & Kharif & Rabi & Summer & Kharif & Rabi & Summer & Kharif & Rabi & Summer \\
\hline Maize-pea-okra & PMH-1 & FVS-1000 & Arka Anamika & 20 & 60 & 15 & $60 \times 15$ & $40 \times 10$ & $60 \times 50$ & $120: 60: 40$ & $25: 50: 50$ & $70: 40: 40$ \\
\hline $\begin{array}{l}\text { Maize-mustard-green } \\
\text { gram }\end{array}$ & PMH-1 & Pusa-25 & SML-668 & 20 & 6 & 20 & $60 \times 15$ & $50 \times 10$ & $30 \times 10$ & $120: 60: 40$ & $60: 60: 40$ & $20: 40: 30$ \\
\hline Cotton - wheat & $\begin{array}{c}\text { Shriram-6588 } \\
\text { (BG-II) }\end{array}$ & HD-2967 & - & 3 & 100 & - & $75 \times 50$ & $20 \times 10$ & - & $120: 60: 60$ & 120:60:40 & - \\
\hline Bottle gourd-onion & PSPL & $\begin{array}{l}\text { Pusa } \\
\text { Riddhi }\end{array}$ & - & 3 & 8 & - & $250 \times 100$ & $25 \times 10$ & - & $60: 40: 50$ & $120: 60: 80$ & - \\
\hline Okra-wheat & $\begin{array}{c}\text { Arka } \\
\text { Anamika }\end{array}$ & HD-2967 & - & 15 & 100 & - & $60 \times 50$ & $20 \times 10$ & - & $60: 30: 30$ & $120: 60: 40$ & - \\
\hline
\end{tabular}

Table.2 Economic yield of different crops in cropping systems

\begin{tabular}{|c|c|c|c|c|c|c|c|c|c|}
\hline \multirow[t]{3}{*}{ Treatment } & \multicolumn{6}{|c|}{ Economic yield (t/ha) } & \multirow{2}{*}{\multicolumn{3}{|c|}{$\begin{array}{c}\text { Mean of two years (economic yield } \\
\text { t/ha) }\end{array}$}} \\
\hline & \multicolumn{3}{|c|}{ 2015-16 } & \multicolumn{3}{|c|}{ 2016-17 } & & & \\
\hline & Kharif & Rabi & Summer & Kharif & Rabi & Summer & Kharif & Rabi & Summer \\
\hline \multicolumn{10}{|l|}{ Cropping systems } \\
\hline $\mathrm{CS}_{1}:$ Maize - pea - okra & 4.14 & 1.37 & 3.39 & 4.78 & 1.56 & 3.01 & 4.46 & 1.47 & 3.20 \\
\hline $\mathrm{CS}_{2}$ : Maize - mustard - green gram & 4.27 & 1.61 & 0.48 & 4.47 & 1.42 & 0.61 & 4.37 & 1.52 & 0.55 \\
\hline $\mathrm{CS}_{3}$ : Cotton - wheat & 1.95 & 5.12 & - & 2.14 & 5.25 & - & 2.05 & 5.19 & - \\
\hline $\mathrm{CS}_{4}$ : Bottle gourd - onion & 8.12 & 9.01 & - & 8.26 & 10.65 & - & 8.19 & 9.83 & \\
\hline $\mathrm{CS}_{5}:$ Okra - wheat & 5.67 & 5.18 & - & 6.42 & 5.31 & - & 6.05 & 5.25 & \\
\hline
\end{tabular}


Table.3 Straw yield and wheat-grain-equivalent yield of various cropping systems

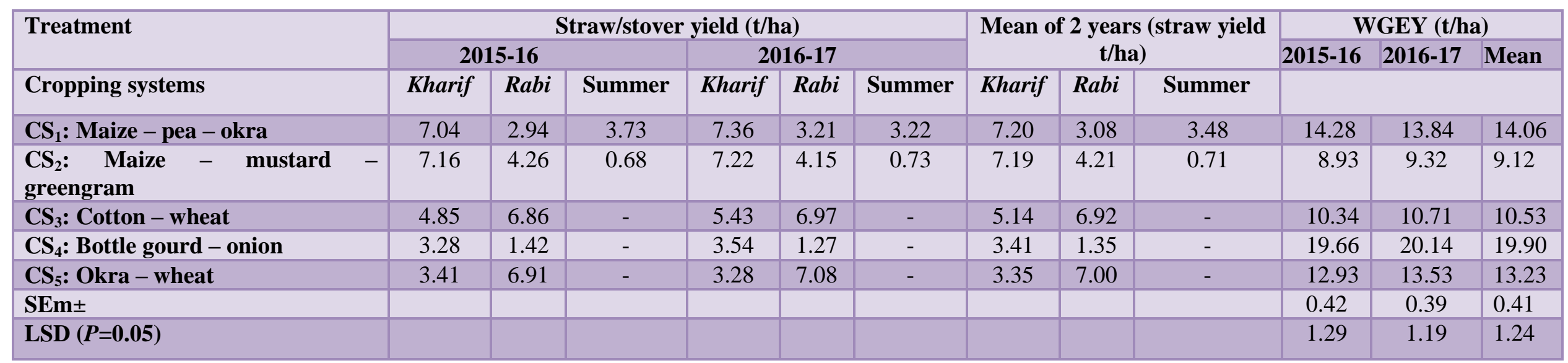

Table.4 Economics (gross returns, cost of cultivation, net returns and returns per rupee invested) of different cropping systems

\begin{tabular}{|c|c|c|c|c|c|c|c|c|c|c|c|c|}
\hline \multirow[t]{2}{*}{ Treatment } & \multicolumn{3}{|c|}{$\begin{array}{c}\text { Gross Returns } \\
\left(\mathbf{x 1 0}^{3} \square / \text { ha }\right)\end{array}$} & \multicolumn{3}{|c|}{$\begin{array}{c}\text { Cost of cultivation } \\
\left(\mathbf{x 1 0}^{3} \square / \mathrm{ha}\right)\end{array}$} & \multicolumn{3}{|c|}{$\begin{array}{l}\text { Net Returns } \\
\left(\mathbf{x 1 0} 0^{3} \square / \text { ha }\right)\end{array}$} & \multicolumn{3}{|c|}{ B:C Ratio } \\
\hline & 2015-16 & 2016-17 & Mean & 2015-16 & $\begin{array}{c}\text { 2016- } \\
17\end{array}$ & Mean & 2015-16 & 2016-17 & Mean & $\begin{array}{c}2015- \\
16\end{array}$ & 2016-17 & Mean \\
\hline \multicolumn{13}{|l|}{ Cropping systems } \\
\hline $\mathrm{CS}_{1}:$ Maize - pea - okra & 217.79 & 224.84 & 221.32 & 95.13 & 100.50 & 97.82 & 122.66 & 124.34 & 123.50 & 2.29 & 2.24 & 2.26 \\
\hline $\begin{array}{l}\mathrm{CS}_{2}: \text { Maize }- \text { mustard - } \\
\text { greengram }\end{array}$ & 136.15 & 151.48 & 143.81 & 68.20 & 72.65 & 70.43 & 67.95 & 78.83 & 73.39 & 2.00 & 2.09 & 2.04 \\
\hline $\mathrm{CS}_{3}:$ Cotton - wheat & 157.67 & 174.12 & 165.90 & 84.62 & 88.27 & 86.45 & 73.05 & 85.85 & 79.45 & 1.86 & 1.97 & 1.92 \\
\hline $\mathrm{CS}_{4}$ : Bottle gourd - onion & 299.76 & 327.36 & 313.56 & 98.85 & 95.58 & 97.22 & 200.91 & 231.78 & 216.34 & 3.03 & 3.42 & 3.23 \\
\hline $\mathrm{CS}_{5}:$ Okra - wheat & 197.24 & 219.87 & 208.55 & 85.20 & 88.30 & 86.75 & 112.04 & 131.57 & 121.80 & 2.31 & 2.49 & 2.40 \\
\hline SEm \pm & - & - & & - & - & & 2.19 & 2.57 & 2.37 & 0.02 & 0.04 & 0.03 \\
\hline $\operatorname{LSD}(P=0.05)$ & - & - & & - & - & & 6.74 & 7.91 & 7.31 & 0.06 & 0.13 & 0.09 \\
\hline
\end{tabular}


Table.5 Energetics (energy input, energy output and energy net returns) of different cropping systems during 2015-16 and 2016-17

\begin{tabular}{|c|c|c|c|c|c|c|c|c|c|c|c|c|}
\hline \multirow[t]{3}{*}{ Treatment } & \multicolumn{4}{|c|}{ Energy input (x10 $\left.{ }^{3} \mathrm{MJ} / \mathrm{ha}\right)$} & \multicolumn{4}{|c|}{ Energy output (x10 $\left.{ }^{3} \mathrm{MJ} / \mathrm{ha}\right)$} & \multirow{2}{*}{\multicolumn{4}{|c|}{$\begin{array}{c}\text { Energy net returns } \\
\text { Mean of two years }\left(\mathrm{x}^{3} 0^{3} \mathrm{MJ} / \mathrm{ha}\right)\end{array}$}} \\
\hline & \multicolumn{4}{|c|}{ Mean of two years $\left(\times 10^{3} \mathrm{MJ} / \mathrm{ha}\right)$} & \multicolumn{4}{|c|}{ Mean of two years $\left(\mathrm{x}^{3} 0^{3} \mathrm{MJ} / \mathrm{ha}\right)$} & & & & \\
\hline & Kharif & Rabi & Summer & Total & Kharif & Rabi & Summer & Total & Kharif & Rabi & Summer & Total \\
\hline \multicolumn{13}{|l|}{ Cropping systems } \\
\hline $\mathrm{CS}_{1}:$ Maize - pea - okra & 13.31 & 6.91 & 12.85 & 33.07 & 195.16 & 59.43 & 49.52 & 304.11 & 181.85 & 52.52 & 36.67 & 271.04 \\
\hline $\begin{array}{l}\mathrm{CS}_{2} \text { : Maize - mustard - green } \\
\text { gram }\end{array}$ & 13.32 & 11.04 & 6.90 & 31.26 & 193.66 & 90.44 & 16.82 & 300.92 & 180.34 & 79.40 & 9.92 & 269.66 \\
\hline $\mathrm{CS}_{3}:$ Cotton - wheat & 15.29 & 16.67 & 0.00 & 31.96 & 88.38 & 162.66 & - & 251.04 & 73.09 & 145.99 & 0.00 & 219.08 \\
\hline $\mathrm{CS}_{4}$ : Bottle gourd - onion & 8.83 & 16.86 & 0.00 & 25.68 & 49.18 & 24.87 & - & 74.05 & 40.35 & 8.02 & 0.00 & 48.37 \\
\hline $\mathrm{CS}_{5}:$ Okra - wheat & 10.89 & 16.35 & 0.00 & 27.24 & 53.30 & 164.54 & - & 217.84 & 42.41 & 148.19 & 0.00 & 190.60 \\
\hline SEm \pm & & & & 0.26 & & & & 7.60 & & & & 3.73 \\
\hline $\operatorname{LSD}(P=0.05)$ & & & & 0.81 & & & & 23.41 & & & & 11.49 \\
\hline
\end{tabular}

Table.6 Energy use efficiency, energy productivity and specific energy of various cropping systems

\begin{tabular}{|c|c|c|c|c|c|c|c|c|c|}
\hline \multirow{3}{*}{$\begin{array}{l}\text { Treatment } \\
\text { Cropping systems }\end{array}$} & \multicolumn{3}{|c|}{ Energy use efficiency } & \multicolumn{3}{|c|}{$\begin{array}{l}\text { Energy productivity } \\
\text { (g/MJ) }\end{array}$} & \multicolumn{3}{|c|}{$\begin{array}{l}\text { Specific energy } \\
\text { (MJ/kg) }\end{array}$} \\
\hline & 2015-16 & \multirow[t]{2}{*}{ 2016-17 } & \multirow[t]{2}{*}{ Mean } & 2015-16 & \multirow[t]{2}{*}{ 2016-17 } & \multirow[t]{2}{*}{ Mean } & \multirow[t]{2}{*}{ 2015-16 } & \multirow[t]{2}{*}{ 2016-17 } & \multirow[t]{2}{*}{ Mean } \\
\hline & & & & & & & & & \\
\hline $\mathrm{CS}_{1}:$ Maize - pea - okra & 9.03 & 9.36 & 9.20 & 432.1 & 414.8 & 423.4 & 2.31 & 2.41 & 2.36 \\
\hline $\begin{array}{l}\mathrm{CS}_{2}: \text { Maize }- \text { mustard - green } \\
\text { gram }\end{array}$ & 9.66 & 9.59 & 9.63 & 286.9 & 296.9 & 291.9 & 3.49 & 3.37 & 3.43 \\
\hline $\mathrm{CS}_{3}:$ Cotton - wheat & 7.66 & 8.05 & 7.86 & 323.8 & 335.0 & 329.4 & 3.09 & 2.98 & 3.04 \\
\hline $\mathrm{CS}_{4}$ : Bottle gourd - onion & 3.18 & 2.60 & 2.89 & 784.0 & 766.3 & 775.2 & 1.28 & 1.31 & 1.29 \\
\hline $\mathrm{CS}_{5}:$ Okra - wheat & 8.05 & 7.95 & 8.00 & 482.1 & 489.5 & 485.8 & 2.07 & 2.04 & 2.06 \\
\hline
\end{tabular}




\section{Output energy}

Maize - pea- okra cropping system produced maximum output energy $\left(304.11 \times 10^{3}\right.$ $\mathrm{MJ} / \mathrm{ha}$ ), because of higher energy equivalents of the produce. It indicates that more energy should be incurred to produce the yield (both grain and straw). The minimum output energy was generated from bottle gourd - onion cropping system $\left(74.05 \times 10^{3} \mathrm{MJ} / \mathrm{ha}\right)$ owing to lower energy values of both bottle gourd and onion.

\section{Net Energy}

Higher net returns of energy was recorded with maize - pea - okra system $\left(271.04 \times 10^{3}\right.$ $\mathrm{MJ} / \mathrm{ha}$ ), and the lower net energy was generated from bottle gourd - onion cropping system (48.37 x $\left.10^{3} \mathrm{MJ} / \mathrm{ha}\right)$.

\section{Energy use efficiency and specific energy}

Maize - mustard - green gram system showed maximum values of mean energyuse efficiency (9.63) and specific energy (3.43 $\mathrm{MJ} / \mathrm{kg}$ ) while minimum was recorded in bottle gourd - onion cropping system (2.89, 334.2 MJ/ha/day,1.29 MJ/kg and 0.76 MJ/ $\square$, respectively) owing to lower energy equivalent values of both bottle gourd and onion (Table 6).

\section{Energy productivity}

Bottle gourd - onion cropping system registered highest energy productivity of $775.2 \mathrm{~g} / \mathrm{MJ}$ owing to more WGEY in comparison to input energy used. Bottle gourd - onion cropping system was followed by okra - wheat system $(485.8 \mathrm{~g} / \mathrm{MJ})$ in terms of energy productivity. These results are in conformity with the findings of Jain et al., (2011). The lowest energy productivity was recorded with maize - mustard - green gram system (291.9 g/MJ). This was obviously owing to lower wheat-grain-equivalent yield in comparison to input energy used.

It can be concluded that bottle gourd - onion cropping system was found to be more productive, profitable followed by maize pea - okra system. The lower input energy, higher energy productivity was registered with bottle gourd - onion cropping system. It clearly indicated that rice-wheat cropping system could be suitably diversified with bottle gourd - onion, maize - pea - okra, cotton - wheat and okra - wheat cropping systems under marginal farmer's situations. These systems not only provide higher productivity and returns, but also provide the farmers a regular income throughout the year.

\section{Acknowledgement}

The award of National fellowship by the University Grants Commission, New Delhi, to B Bhargavi and Institutional support from Indian Agricultural Research Institute (IARI), New Delhi, India, is gratefully acknowledged. Authors are especially thankful to Division of Agronomy, IARI, New Delhi, India for carrying out the present research work.

\section{References}

Baishaya, A. and Sharma, G.L. 1990. Energy budgeting of rice-wheat cropping system. Indian Journal of Agronomy 35 $(1,2): 167-177$.

Behera U K, Sharma A R and Mahapatra I C. 2007. Crop diversification for efficient resource management in India: Problems, prospects and policy. Journal of Sustainable Agriculture, 30(3): 97127.

Bhatt R, Kukal S S, Busari M A, Arora S and Yadav M. 2016. Sustainability issues on rice-wheat cropping system. International Soil and Water Conservation Research, 4(1): 64-74. 
Bhullar M S and Chauhan B S. 2015. Seed bank dynamics and emergence pattern of weeds as affected by tillage systems in dry direct-seeded rice. Crop Protection, 67: 168-177.

DassAnchal, Sudhishri, S, Patnaik U S. and Lenka NK. 2009. Effect of agronomic management on watershed productivity, impact indices, crop diversification and soil fertility in eastern ghats of Orissa. Journal of Soil and Water Conservation, 8(3): 34-42

Hira G S. 2009. Water management in northern states and the food security of India. Journal of Crop Improvement, 23(2): 136-157.

Jain T C. 2008. New paradigms in agronomic research and development. Indian Journal of Agronomy, 53(4): 241-244.

Jain N K, Singh H, Dashora L N and Mundra $\mathrm{S}$ N. 2015. Diversification and intensification of maize (Zea mays)wheat (Triticum aestivum) cropping system for sustainable productivity and profitability. Indian Journal of Agronomy, 60(1): 38-44.

Jat R A, Dungrani R A, Arvadia M K and Sahrawat K L. 2012. Diversification of rice (Oryza sativa L.)-based cropping systems for higher productivity, resource-use efficiency and economic returns in south Gujarat, India. Archives of Agronomy and Soil Science, 58(6): 561-572.

Khan, S A., Malav, L C., Kumar, S, Malav, K. and Gupta, N. 2016.Resource utilization of biogas slurry for better yield and nutritional quality of baby corn. Advances in Environmental and Agricultural Science, 382-394.

Kumar A, Tripathi H P, Yadav R A and Yadav D S. 2008. Diversification of rice (Oryza sativa)-wheat (Triticum aestivum) cropping system for sustainable production in eastern Uttar Pradesh.Indian Journal of Agronomy,
53(1): 18-21.

Mahapatra I C and Behera U K 2011.Ricebased farming systems for livelihood improvement of Indian farmers. Indian Journal of Agronomy, 56(1): 1-19.

Mishra MM, Nanda S S, Mohanty M, Pradhan K C and Mishra SS. 2007.Crop diversification under rice-based cropping system in western Orissa. (In) Extended Summaries of $3^{\text {rd }}$ National Symposium on Integrated Farming Systems and its Role towards Livelihood Improvement, organized by Farming Systems Research and Development Association, 26-28 October, Agricultural Research Station, Durgapura, Jaipur, pp. 154-56.

Mittal, J P. and Dhawan, K C. 1988.Research manual on energy requirements in agricultural sector, ICAR, New Delhi: 20-23.

Prasad D, Yadava M S and Singh C S. 2013. Diversification of rice (Oryza sativa) based cropping systems for higher productivity, profitability and resourceuse efficiency under irrigated ecosystem of Jharkhand. Indian Journal of Agronomy, 58(2): 77-83.

Reddy, AA. 2014. Profitability and labour use in cropping systems. Indian Journal of Dryland Agricultural Research and Development, 29(1): 97-106.

Shah M S, Verma N and Vishwkarma S K. 2015. Paper Diversification of rice (Oryza sativa)-based cropping systems for higher production efficiency, water productivity and economic viability in Madhya Pradesh. Indian Journal of Agronomy, 60(1): 25-30.

Sharma H R. 2007. Crop diversification in Himachal Pradesh: extent, impact, determinants and challenges. Indian Journal of Labour Economics, 50(4): 689-702.

Singh, M.K., Pal, S.K., Thakur, R. and Verma, U.N. 1997. Energy input-output 
relationship of cropping systems. Indian Journal of Agricultural Sciences, 67(6): 262-264.

Singh P, Singh J P, Gill M S and Singh Y. 2007. Alternate cropping systems to sugarcane-ratoon-wheat in peri urban areas of Meerut. (In) Extended summaries 3rd National Symposium on Integrated Farming Systems, October 26-28, 2007, organized by Farming System and Development Association (Project Directorate for Cropping System Research, Modipuram, Meerut) at Agricultural Research Station, Durgapura, Jaipur.

Singh M K, Singh S P and Ujjwal V. 2017.
Alternative Arable Cropping Strategies: A Key to Enhanced Productivity, Resource-Use-Efficiency, and SoilHealth under Subtropical Climatic Condition. International Journal of Current Microbiology and Applied Sciences, 6(11): 1187-1205.

Soni V. 2012. Groundwater loss in India and an integrated climate solution. Current Science, 102(8): 1098-1101.

Uddin M J, Quayyum M A and Salahuddin K M. 2009. Intercropping of hybrid maize with short duration vegetables at hill valleys of Bandarban. Bangladesh Journal of Agricultural Research, 34(1): 51-57.

\section{How to cite this article:}

Bhargavi, B. and Behera, U.K. 2019. System Productivity and Energetics of High-Value Crops Embedded Diversified Cropping Systems. Int.J.Curr.Microbiol.App.Sci. 8(01): 1895-1905. doi: https://doi.org/10.20546/ijcmas.2019.801.199 